\title{
LA PROTECCIÓN JURÍDICA DE LA VIDA ANTE EL TRIBUNAL DE ESTRASBURGO: UN DERECHO EN TRANSFORMACIÓN Y EXPANSIÓN
}

\author{
Fernando Rey Martínez \\ Universidad de Valladolid (España) \\ rey17@ono.com
}

Sumario: I. Introducción. Viejas y nuevas dimensiones del derecho a la vida. II. Protección del Convenio ante las muertes causadas por agentes del Estado: A) Uso desproporcionado de la fuerza por parte de agentes de la autoridad; B) El caso de los desaparecidos tras su detención por fuerzas de seguridad; C) Tortura y muerte en dependencias policiales. III. Las decisiones sobre el final y el comienzo de la vida: suicidio asistido y estatuto jurídico del feto. IV. La protección estatal ante ciertos tipos de riesgo para la vida: A) Riesgos provenientes de terceros; B) Riesgos procedentes de daños medioambientales; C) Valoración por el Tribunal de sistemas penales y penitenciarios estatales a fin de examinar si protegen suficientemente la vida o reparan adecuadamente su pérdida. V. Conclusiones finales. VI. Anexo de jurisprudencia.

\section{INTRODUCCIÓN. VIEJAS Y NUEVAS DIMENSIONES DEL DERECHO A LA PROTECCIÓN JURÍDICA DE LA VIDA}

El art. 2 del Convenio de Roma dispone que:

“1. El derecho de toda persona a la vida está protegido por la ley. Nadie podrá ser privado de su vida intencionadamente, salvo en ejecución de una condena que imponga pena capital dictada por el tribunal al reo de un delito para el que la ley establece esa pena. 2. La muerte no se considerará infligida con infracción del presente artículo cuando se produzca como consecuencia de un recurso a la fuerza que sea absolutamente necesario: a) En defensa de una persona contra una agresión ilegítima. b) Para detener a 
una persona conforme a derecho o para impedir la evasión de un preso o detenido legalmente. c) Para reprimir, de acuerdo con la ley, una revuelta o insurrección".

La redacción de este precepto no suscitó demasiados problemas en los trabajos preparatorios de la Convención y su objetivo principal parecía ser, en origen, legitimar la pena de muerte y declararla compatible con el sistema europeo de protección de derechos bajo ciertas condiciones. ${ }^{1}$ De la paradójica impresión que esto pudiera provocar en la actualidad, tratándose de una disposición de protección jurídica de la vida, hay que descontar el hecho de que en la época de su aprobación bastantes países del Consejo de Europa disponían de la pena de muerte en su arsenal de sanciones penales más graves. Este sentido inicial del art. 2 ha ido, obviamente, perdiendo vigor debido a la evolución abolicionista de la mayoría de los Estados miembros del Consejo de Europa, tendencia que, según la propia exposición de motivos, es la razón justificativa del Protocolo no 6 relativo a la abolición de la pena de muerte (28 de abril de 1983²).

El Protocolo no 6 entró en vigor el 1 de marzo de $1985 .{ }^{3}$ De él se ha observado que su redacción es "original" porque, a diferencia de otros preceptos internacionales que obligan a los Estados miembros a abolir la pena de muerte (como, por ejemplo, el art. 1.2 del segundo Protocolo facultativo del Pacto internacional de derechos civiles y políticos), el art. 1 del Protocolo no 6 prohíbe directamente tal sanción con una fórmula que le asemeja más a una norma interna de rango constitucional que a una de derecho internacional, otorgando un derecho subjetivo a los particulares a no ser condenados a tal pena y, mucho menos, a ser ejecutados. La Comisión de Derechos Humanos ha tenido la oportunidad de examinar algunos recursos en los que se invocaba la violación del Protocolo $n$ o 6 en relación con solicitudes de extradición de Estados que aplicaban aún la pena de muerte, concluyendo que la concesión de dicha extradición podría violar la norma, así como también el art. 3 del Convenio, que prohíbe los tratos inhumanos. ${ }^{4}$ En estos casos de fundado temor de riesgo para la vida del recurrente, la Comisión solía utilizar la medida cautelar prevista en el art. 36 de su Reglamento Interno, recomendando al Estado no proceder a la extradición. De hecho,

\footnotetext{
1 Los trabajos preparatorios son de escaso interés para la comprensión de la disposición. La primera frase se inspira en el art. 3 de la Declaración Universal de los Derechos del Hombre y el resto del precepto fue propuesto por la delegación británica.

2 Artículo 1. Abolición de la pena de muerte. Queda abolida la pena de muerte. Nadie podrá ser condenado a tal pena ni ejecutado. Artículo 2. Pena de muerte en tiempo de guerra. Un Estado podrá prever en su legislación la pena de muerte por actos cometidos en tiempo de guerra o de peligro inminente de guerra; dicha pena solamente se aplicará en los casos previstos por dicha legislación y con arreglo a lo dispuesto en la misma. Dicho Estado comunicará al Secretario General del Consejo de Europa las correspondientes disposiciones de la legislación de que se trate. A rtículo 3. Prohibición de derogaciones. No se autorizará excepción alguna a las disposiciones del presente Protocolo invocando el artículo 15 del Convenio. Artículo 4. Prohibición de reservas. No se aceptará reserva alguna a las disposiciones del presente Protocolo en virtud del artículo 57 del Convenio.

3 En España, uno de los cinco primeros Estados en hacerlo, fue ratificado el 20 de diciembre de 1984 (el Instrumento de ratificación fue publicado en el B.O.E. de 17 de abril de 1985).

4 Recuérdese el famoso Caso Soering v. Reino Unido, de 7 de julio de 1989.
} 
la Comisión concedía a los Estados miembros del Protocolo no 6 la facultad de dar trámite a la extradición solicitada por países que reconocían la pena de muerte sólo a condición de que ofrecieran garantías suficientes de que tal pena no se infligiría. ${ }^{5}$ Recientemente, en el Caso F.H. v. Suecia, de 20 de enero de 2009, el Tribunal se ha negado a estimar violado el art. 2 del Convenio por la denegación sueca de asilo a un iraquí cristiano que alegaba temor por su vida en Irak ya que no demostró un riesgo real en este sentido, ${ }^{6}$ pero en Bader y Kanbor v. Suecia, de 8 de noviembre de 2005 sí consideró que la denegación de asilo de los reclamantes y su devolución a Siria sí les ponía en serio riesgo de ser allí ejecutados.

El último paso de la evolución del Consejo de Europa en contra de la pena de muerte ha sido el Protocolo número 13 del Convenio de Roma, relativo a la abolición de la pena de muerte en todas las circunstancias (también en tiempo de guerra o de conflicto), firmado en Vilnius el 3 de mayo de 2002 y que ha entrado en vigor el 1 de julio de 2003. ${ }^{7}$

El giro copernicano del sentido inicial del art. 2, cuyo ámbito de protección principal se dirigía a someter la pena de muerte a límites básicos como el principio de legalidad penal y ciertas garantías procesales y que debe ser leído ahora a la luz del principio abolicionista del Protocolo no $6^{8}$ desde el 1 de marzo de 1985, fecha de su entrada en vigor, no convierte en este punto, sin embargo, al art. 2 en un fósil jurídico porque su aplicación todavía podría admitirse en la hipótesis de "tiempo de guerra" o de "caso de peligro inminente de guerra" (art. 2 del Protocolo n. 6). Pero, sobre todo, y como tendremos ocasión de comprobar, el art. 2 del Convenio se ha revelado como una garantía útil frecuentemente utilizada (por desgracia) frente a agresiones a la vida

5 A la Comisión no le bastaba, sin embargo, con la simple declaración del Estado solicitante de no aplicar la pena, sino que procedía a analizar la estructura constitucional de tal Estado. Así, por ejemplo, ocurrió en los asuntos Aylor Davis v. France (20 de enero de 1994) o Venecia v. Italia, de 21 de noviembre de 1996, en los que la Comisión recomendó a Francia y a Italia denegar la extradición a Texas y Florida, respectivamente, por considerar insuficientes las garantías ofrecidas por tales Estados.

6 El recurrente argumentaba que sería perseguido, en primer lugar, por su fe cristiana, pero el Tribunal consideró que los cristianos en Irak eran protegidos por las fuerzas de seguridad y los documentos de identidad no mencionaban la religión, y, en segundo lugar, porque había pertenecido a las Guardias Republicanas y al partido Baaz, pero el Tribunal sostuvo que el recurrente no había participado en hechos de sangre y, además, esa Guardia había sido integrada en el nuevo ejército.

7 En este Protocolo se abole la pena de muerte en todo caso (art. 1), prohibiéndose cualquier derogación (art. 2) y/o reserva (art. 3). España, que fue uno de los primeros Estados en ratificar el Protocolo número 6 , no ha ratificado por el momento este Protocolo 13. El art. 15 de la Constitución prohíbe la pena de muerte "salvo lo que puedan disponer las leyes penales militares para tiempos de guerra", pero esta disposición no prohibiría que España ratificara el Convenio porque en ella no se contiene una obligación de prever la pena de muerte en el supuesto que se describe, sino, tan sólo, una posibilidad permitida a la cual se renunciaría (válidamente a mi juicio) en caso de ratificar el Protocolo

8 Idéntica evolución ha experimentado el art. 4 de la Convención Américana de Derechos Humanos, precepto que muestra más claramente la finalidad de someter la pena de muerte a límites estrictos, pero también debe leerse, hoy en día, a la luz del Protocolo relativo a la abolición de la pena de muerte adoptado en A sunción (Paraguay) el 6 de agosto de 1990. 
humana por parte de agentes de la autoridad pública en un escenario seguramente no imaginado por los redactores del Convenio, el de la lucha contra el terrorismo de base nacionalista. Desde este punto de vista puede hablarse de una transformación del ámbito de aplicación ordinario del art. 2, de simple cláusula habilitadora bajo ciertas condiciones de la pena de muerte a garantía contra los excesos estatales en la lucha antiterrorista. El centro de gravedad del precepto ha transitado de la segunda frase del primer párrafo al segundo párrafo, relativo a los límites del "recurso a la fuerza absolutamente necesario" que pueda producir eventualmente la muerte de una persona. En paralelo a este proceso, el Tribunal ha ido hallando nuevas dimensiones de protección del derecho a la vida, ampliando las tradicionales, al considerar violado el art. 2 no sólo por las acciones estatales, sino también por sus omisiones ante cierto tipo de riesgos para la vida de los ciudadanos. ${ }^{9}$

Con carácter general, el derecho a la protección jurídica de la vida tiene, ciertamente, una estructura peculiar. Así, cabría subrayar, entre otras, singularidades como éstas: (1aㅡ) es el presupuesto lógico y ontológico del resto de derechos. (2aㅡ) Su violación tiene, por definición, “carácter irreversible porque implica la desaparición de su titular". ${ }^{10}$ (3a) Si se tiene en cuenta que la misma noción de "vida" humana presenta contornos científicos esquivos en la definición tanto de su origen como de su final y que es un concepto central de tradiciones religiosas y morales, se explica que el derecho a la vida sea un terreno particularmente fértil para el debate ideológico ${ }^{11}$ y jurídico (ahí está, por ejemplo, la auténtica guerra de trincheras conceptual en los casos del aborto voluntario y de la eutanasia/suicidio asistido). Pocas dudas ofrece el hecho de que la protección jurídica de la vida es un derecho de defensa de toda persona frente a los poderes públicos del que se derivarían una prohibición y una obligación: los Estados estarían vinculados de modo negativo, pues el art. 2 les prohíbe causar la muerte a nadie a través de sus agentes (salvo en los supuestos de "recurso a la fuerza

9 Similar evolución ha ido experimentado la jurisprudencia de la Corte Interamericana de Derechos Humanos. Allí, incluso, y al menos en relación con menores, se ha llegado a conectar el derecho a la vida con "el acceso a las condiciones que garanticen una existencia digna" (párrafo 144, Sentencia Villagrán Morales y otros, caso "niños de la calle", de 19 de noviembre de 1999). Cinco jóvenes fueron asesinados por policías hondureños; el Tribunal entendió que ello se debía a la práctica común que en ese momento existía en Honduras contra los niños de la calle por parte de algunos agentes de la autoridad. En el párrafo 191, el Tribunal afirmó: "cuando los Estados violan, en esos términos, los derechos de los niños en situación de riesgo, como los "niños de la calle", los hacen víctimas de una doble agresión. En primer lugar, los Estados no evitan que sean lanzados a la miseria, privándolos así de unas mínimas condiciones de vida digna e impidiéndoles el "pleno y armonioso desarrollo de su personalidad", a pesar de que todo niño tiene derecho a alentar un proyecto de vida que debe ser cuidado y fomentado por los poderes públicos para que se desarrolle en su beneficio y en el de la sociedad a la que pertenece. En segundo lugar, atentan contra su integridad física, psíquica y moral, y hasta contra su propia vida".

10 L. Ma Diez-Picazo, Sistema de Derechos Fundamentales, Thomson/Civitas, Madrid, 2003, p. 189.

11 Como concluye R. Dworkin su influyente análisis (El dominio de la vida. Una discusión acerca del aborto, la eutanasia y la libertad individual, A riel, Barcelona, 1994, p. 311), el "verdadero debate" se produce porque todo el mundo asume "la santidad o inviolabilidad, en cualquier etapa en que se encuentre, de cualquier vida humana", pero discrepa sobre el "lugar adecuado" que puedan jugar en este campo las elecciones personales, el ejercicio de "la libertad individual", que es el "requerimiento cardinal y absoluto del autorrespeto" (p. 313). 
absolutamente necesario", que deben interpretarse de modo muy estricto, del apartado segundo del art. 2 del Convenio y del estrecho margen que aún subsiste para la aplicación de la pena de muerte en los términos del art. 2 del Protocolo no 6 para el tiempo de guerra), pero, muy particularmente, los poderes públicos estarían obligados, en un sentido positivo, a establecer sistemas efectivos de protección jurídica de la vida en sus respectivos ordenamientos. Es esta última dimensión la que permite a las instituciones garantizadoras del Convenio examinar no sólo acciones estatales, sino también sus omisiones, lo que permite amplificar y afilar su ámbito de control.

A hora bien, así como no se discute que la protección jurídica de vida sea un derecho de defensa, el conflicto exegético más agudo y complejo que se plantea actualmente, tanto en el ámbito europeo como en el constitucional de la mayoría de los Estados, es el de valorar si se trata o no de un derecho de libertad en el sentido de que sus titulares puedan, bajo ciertas condiciones, disponer de su propia vida (eutanasia y/o suicidio asistido). El Tribunal Europeo, en el Caso Pretty v. Reino Unido, de 29 de abril de 2002, ha tenido ocasión de pronunciarse sobre tan espinoso asunto, pero de su decisión no se deduce la directa incompatibilidad del suicidio asistido con el Convenio, sino tan sólo que no se encuentra amparado por el art. 2. A mi juicio, se trata de una Sentencia dilatoria, en la que el TEDH ha optado, prudentemente, por no zanjar de modo definitivo una discusión que, sin arrojar resultados claros aún, está dividiendo a la opinión pública y a los operadores jurídicos de los diversos Estados. En cualquier caso, de la interpretación del Tribunal sí puede deducirse que, hoy por hoy, el derecho a la vida no incluye la facultad para su titular de disponer de ella. La vida es un bien jurídico protegido con independencia de la voluntad de su titular, lo que, a la vez que convierte en problemática su adscripción a la categoría clásica de derecho subjetivo, ${ }^{12}$ explicita la importancia de su dimensión objetiva o extraindividual. Se trataría de un bien indisponible por su directa conexión con la misma conservación del núcleo social. ${ }^{13}$

La formulación del primer párrafo del art. 2.1 del Convenio es concisa y, a mi juicio, más precisa, desde el punto de vista técnico, que la del concordante art. 15 de la Constitución española. Mientras que éste dispone que "todos tienen derecho a la vida", el

12 Así, por ejemplo, para no pocos autores, entre los cuales ya se encontraba Santi Romano, el derecho a la vida "no constituye un derecho subjetivo, sino un bien que es protegido objetivamente, lo que explica sus efectos prescindiendo incluso de la voluntad del individuo, e incluso contra su voluntad, en la medida en que no tiene valor alguno la renuncia a la vida del mismo individuo... en otros términos, se trata de una protección absoluta y más completa de la que acompaña a la figura del derecho subjetivo, que implica la facultad de hacerla valer o no" (Corso di Diritto Costituzionale, Padua, 1933, p. 365).

13 En este sentido hay quien, como Ida Nicotra (Vita e sistema dei valori nella Costituzione, Giuffrè, 1997, pp. 3 ss.), ha observado las analogías entre el bien jurídico "vida" y otros bienes como el "ambiente" o el "patrimonio artístico". Respecto de tales bienes indisponibles, extraindividuales, etc., tanto la persona singular como la colectividad organizada no podrían considerarse auténticamente como "titulares", sino tan sólo como "administradores" (p. 8) a los que correspondería conservar tales bienes según su finalidad propia y transferirlos a las generaciones futuras, en virtud del principio de "justicia entre generaciones". Ciertamente, la "vida", a diferencia del "ambiente", se puede y debe referir a una persona concreta por lo que es más fácil asimilar la protección jurídica de la vida a la categoría de derecho subjetivo. 
Convenio establece que "el derecho de toda persona a la vida está protegido por la ley". ${ }^{14}$ La redacción del texto europeo permite, en efecto, entender que lo que se otorga por el Convenio a toda persona es un derecho a la protección jurídica de su vida, esto es, que la naturaleza de la disposición es la propia de una garantía. El Derecho no puede asegurar la vida, sino la protección jurídica de la vida. Sin embargo, la literalidad del texto constitucional español parece sugerir que lo que se concede a "todos" es un derecho subjetivo a la vida, lo cual es absurdo dada la natural obstinación del hecho de la muerte. Tampoco es posible reconocer un derecho a la salud, sino un derecho a la protección de la salud, y en este punto la redacción del art. 43.1 CE, por ejemplo, es bastante más precisa. Sin embargo, el art. 2 del Convenio de Niza ${ }^{15}$ contiene una formulación más parecida a la española que a la del Convenio de Roma: "Toda persona tiene derecho a la vida". En su segundo párrafo añade: "Nadie podrá ser condenado a la pena de muerte ni ejecutado". La sobria elegancia del tenor literal de la disposición de la Unión sería más apreciable si en Europa hubieran desaparecido, definitivamente, los bajos fondos en los departamentos de seguridad de todos Estados, pero éste no es aún el caso, como lo demuestra la abundante jurisprudencia condenatoria de excesos estatales (particularmente británicos, búlgaros, rusos y turcos). De ahí que una redacción más completa y limitativa de tales excesos como la contemplada en el párrafo segundo del art. 2 del Convenio de Roma ofrezca por ahora mayores garantías.

El art. 2 del Convenio pertenece al denominado "núcleo duro" del Convenio, es decir, al conjunto de derechos que, por efecto de la reserva contenida en el art. 15.2 del Convenio, no pueden ser derogados en ningún supuesto, ni siquiera "en caso de guerra o de otro peligro público que amenace la vida de la nación" (art. 15.1). Desde el seminal Caso McCann y otros v. Reino Unido, de 27 de septiembre de 1995, el Tribunal viene repitiendo que: "El art. 2, que protege el derecho a la vida y establece las circunstancias bajo las que la privación de la vida podría estar justificada, figura como una de las más fundamentales disposiciones de la Convención, que no puede ser derogada de ningún modo en tiempo de paz según el art. 15. Junto con el art. 3, constituye uno de los valores básicos de las sociedades democráticas que componen el Consejo de Europa". De aquí deriva el Tribunal dos relevantes (así como previsibles y generales) consecuencias: (1 $\left.{ }^{a}\right)$ Los límites de este derecho deben interpretarse de modo especialmente restrictivo ("las circunstancias bajo las que la privación de la vida podría estar justificada deben ser estrictamente construidas"). Como veremos, el Tribunal va a utilizar el examen judicial más estricto y astringente posible a la hora de examinar las posibles violaciones de este derecho (comparable al strict scrutiny test de la jurisprudencia del Tribunal Supremo norteamericano), lo que normalmente resultará fatal para las conductas analizadas desde el punto de vista de su adecuación al Convenio. En el Caso A ktas v. Turquía, de 24 de abril de 2003, el Tribunal se refiere a un escrutinio

14 Obviamente, la referencia a la "ley" aquí debe interpretarse en sentido amplio como equivalente a “Derecho". La Comisión, en X v. Irlanda (1977), ha indicado, en este sentido, que la expresión citada no se dirige en exclusiva al legislador, sino que se refiere a la obligación general de todas las autoridades de adoptar las medidas apropiadas para proteger la vida.

15 Art. II-2 del Proyecto de Tratado por el que se instituye una Constitución para Europa. 
particularmente minucioso (particularly thorough scrutiny), incluso aunque hayan tenido ya lugar procedimientos e investigaciones en el orden interno. (2a) De la fundamentalidad del derecho resultaría un principio en favor de la elección de aquella interpretación de su sentido y alcance que haga su contenido "más práctico y efectivo".

Lo cierto es que el acta de nacimiento jurisprudencial del derecho a la protección de la vida se levanta tan sólo en el año 1995, con la citada Sentencia McCann, ${ }^{16}$ pero desde entonces para acá se ha producido una espectacular eclosión de Sentencias, que giran, fundamentalmente, sobre dos escenarios críticos para los derechos humanos, incluido el derecho del art. 2 del Convenio: la lucha turca contra la minoría kurda y la británica contra los nacionalistas irlandeses, aunque también los excesos rusos contra la población chechena han sido registrados. La primera de ellas, especialmente represiva y cruel, consume casi dos de cada tres Sentencias en esta materia, aunque su frecuencia parece disminuir desde el año 2002. Se muestran aquí dos de los efectos, en mi opinión, más importantes del impacto del sistema europeo de protección de derechos sobre los sistemas nacionales, el de funcionar como air-bag de seguridad en casos extremos (por ejemplo, el de los posibles excesos de la lucha antiterrorista) pero también, al estilo de una suerte de ITV, como instrumento ordinario de detección o chequeo de errores y disfunciones concretas en los sistemas de reconocimiento y aplicación de los derechos fundamentales en los ordenamientos jurídicos nacionales. ${ }^{17}$

En la jurisprudencia del TEDH sobre el derecho a la protección de la vida del art. 2, son discernibles varios temas específicos. Dos de ellos absolutamente clásicos, la dimensión que podríamos denominar negativa de la garantía, la prohibición de la pena de muerte, denominada por el Tribunal Constitucional Federal alemán "asesinato organizado legalmente", ${ }^{18}$ salvo dentro del astringente marco jurídico de limitaciones, y la dimensión positiva, que obliga a los poderes públicos a establecer un sistema de protección (incluso penal) que sancione cualquier agresión a la vida con independencia de su origen público o privado (ahí se ubicarían los recurrentes temas del aborto y la eutanasia). Los otros temas, que pueden incluirse asimismo en la dimensión positiva de la garantía, son más novedosos y aluden a la protección que se exige al Estado ante cierto tipo de riesgos serios contra la vida de terceros y también al establecimiento de un sistema de normas que efectivamente protejan la vida o permitan una reparación suficiente. En ambos casos, se avanza, obviamente, el estándar de protección del Convenio y, por ello, se trata de una línea jurisprudencial tan atractiva desde el punto de vista ideológico como peligrosa desde un prisma jurídico por las enormes posibilidades de control de las legislaciones nacionales que se abren para el Tribunal Europeo. Así pues, la interpretación por parte de esta institución del art. 2 puede nuclearse en torno a los siguientes tres escenarios conflictivos:

16 Por ello los trabajos doctrinales sobre el art. 2 del Convenio anteriores a esa fecha (la mayoría) tienen, por fuerza, sólo un valor limitado. A penas hay bibliografía actualizada sobre este precepto.

17 Tampoco debe olvidarse el no menos importante efecto (constitucionalizado implícitamente en el art. $10.2 \mathrm{CE}$ ) de la recepción interna a efectos exegéticos de las decisiones del TEDH.

18 BVerGe I, 97 (105). 
(1) El asunto que aglutina el mayor número de Sentencias es el de la muerte causada por agentes del Estado: ${ }^{19}$ la compatibilidad con el Convenio del planeamiento y ejecución de operaciones de las fuerzas de seguridad en las que resulta muerto alguna persona, así como el uso desproporcionado de la fuerza, epígrafe en el que cabe incluir los casos de los desaparecidos tras su arresto por las autoridades y el de los torturados y asesinados en dependencias policiales.

(2ㅇ) El tema, también tradicional, del final de la vida (eutanasia y/o suicidio asistido) y, en menor medida, porque aún no se ha abordado directamente, de su comienzo (aborto voluntario).

(3) La protección estatal ante cierto tipo de riesgos para la vida. Este punto se refiere a la defensa que cabe esperar de las autoridades nacionales, derivada del art. 2 , ante el riesgo de muerte de una persona a manos de otra, el riesgo derivado de daños medioambientales graves, así como la valoración por los órganos del Convenio de los sistemas procesal y penitenciario internos a fin de examinar si protegen suficientemente la vida de los ciudadanos o permiten una reparación adecuada en caso de su privación injustificada.

\section{PROTECCIÓN DEL CONVENIO ANTE LAS MUERTES CAUSADAS POR AGENTES DEL ESTADO}

La Sentencia de referencia en general sobre el derecho a la protección jurídica de la vida y particularmente sobre este aspecto es la citada McCann y otros v. Reino Unido, de 27 de septiembre de 1995. El supuesto que da origen a la controversia es la muerte de tres activistas del IRA a manos de miembros de las fuerzas especiales británicas en Gibraltar. El Tribunal invoca, con carácter propedeútico, los principios arriba enunciados, del principio de interpretación más efectiva del derecho, de interpretación restrictiva de sus límites y de la fundamentalidad del art. 2 en el sistema de la Convención, principios que van a ser reiterados, incluso literalmente, en gran número de las Sentencias posteriores sobre el art. 2 . A continuación, precisa el sentido y alcance de la expresión "recurso a la fuerza absolutamente necesario" del apartado segundo del precepto, que es un requisito común a los tres límites del derecho que allí se especifican, concluyendo que:

a) La protección del art. 2 se extiende no sólo a muertes causadas por agentes públicos de modo intencionado, sino también a las muertes que sean un resultado no deseado del uso de la fuerza.

b) La expresión "absolutamente necesario" del art. 2.2 indica que debe emplearse un test más estricto y se debe exigir mayor necesidad en comparación con el normal-

19 En la jurisprudencia no se distingue, sino que se hace equivaler dentro de este concepto general, así como del de "fuerzas de seguridad", a los miembros de las Fuerzas Armadas y de la Policía. 
mente empleado de "necesario en una sociedad democrática" según el párrafo segundo de los arts. 8 a 11 de la Convención. En particular, "la fuerza debe utilizarse de un modo estrictamente proporcionado para conseguir los objetivos establecidos en el art. 2.2".

c) El Tribunal "debe someter las privaciones de la vida al más cuidadoso escrutinio, particularmente cuando se emplea un uso deliberado y letal de la fuerza, tomando en consideración no sólo las acciones de los agentes del Estado..., sino también las circunstancias concurrentes, incluyendo asuntos como la planificación y control de las acciones bajo examen".

A plicando estas pautas al caso, el Tribunal concluye que ha habido una violación del art. 2 del Convenio por una deficiente organización y control de la operación. ${ }^{20}$

Con la Sentencia McCann inaugura el TEDH un protocolo de análisis de las operaciones de las fuerzas de seguridad que utilizará en ocasiones posteriores. En el Caso Andronicou y Constantinou v. Chipre, de 9 de octubre de 1997, el Tribunal juzga si vulneró el art. 2, desde esta óptica, una operación de rescate en la que resultaron muertos por las fuerzas de seguridad la secuestrada y el secuestrador (que era su pareja, por cierto ${ }^{21}$ ). Los demandantes, padres de la secuestrada, alegaban que el planeamiento y control de la operación policial fue deficiente porque el negociador carecía de experiencia, no se aseguró una línea de teléfono, había demasiada policía en el entorno en contra del deseo del secuestrador, etc. El TEDH, después de examinar todas las circunstancias del caso, concluyó, sin embargo, que la operación se planeó y ejecutó de una manera que minimizaba el posible riesgo para la vida de la pareja, por lo que no habría habido fractura del art. 2. En Ergi v. Turquía, de 28 de julio de 1998, la conclusión alcanzada es, sin embargo, la opuesta. Un civil kurdo muere, en el sureste de Turquía, como consecuencia de una operación militar lanzada contra el Partido de los Trabajadores del Kurdistán (PKK). Aunque el Tribunal aprecia una "insuficiente

20 Los soldados británicos actuaron creyendo que los activistas del IRA iban a detonar la bomba que supuestamente habían colocado en un coche, por lo que dispararon a matar para evitar que pudieran accionarla mediante control remoto. Se comprobó después, sin embargo, que los muertos iban desarmados, que no tenían detonador alguno y que tampoco había ninguna bomba. El Tribunal no considera, empero, que la acción de comando violara el art. 2 porque "las fuerzas antiterroristas británicas tuvieron que decidir sobre hipótesis incompletas" (aunque con la seguridad de que los tres sospechosos eran miembros del IRA y expertos en explosivos), los irlandeses fueron disparados después de "haber hecho movimientos amenazadores hacia una bolsa de mano como si fueran a detonar la bomba" y los soldados "creían honestamente" que tenían que disparar a matar para salvar vidas inocentes. La violación del art. 2 del Convenio procede, más bien, a juicio del Tribunal, del hecho de que "las autoridades carecieron de control apropiado en la organización y ejecución de la operación de arresto". En efecto, no previnieron la entrada de los sospechosos en Gibraltar, no contrastaron las informaciones procedentes del servicio de inteligencia y los soldados recurrieron al automático recurso a la fuerza letal al abrir fuego. Por ello, "el Tribunal no está persuadido de que la muerte de los tres terroristas constituya un uso de la fuerza absolutamente necesario en defensa de las personas contra una agresión ilegítima en el sentido del art. 2.2.a)".

21 El secuestrador amenazaba con matarla a ella y suicidarse después él. 
base probatoria" para sostener, "más allá de toda duda razonable", que dicho civil fuera asesinado por las fuerzas de seguridad, el planeamiento y ejecución de la operación "puso en riesgo real las vidas de la población civil al exponerla al fuego cruzado entre las fuerzas de seguridad y las del PKK". Y, además, "el Gobierno no ha aportado información alguna que desvirtúe la opinión de que puede ser razonablemente inferido que haya adoptado suficientes precauciones para proteger las vidas de la población civil". Similar razonamiento y fallo alcanza el TEDH en los casos 0 gur v. Turquía, de 20 de mayo de 1999, Gül v. Turquía, de 14 de diciembre de 2000, Mansuroglu v. Turquía, de 26 de febrero de 2008 , o, en relación con la muerte no intencional de un joven por un policía durante su arresto, en Juozaitiene y Bikulcius v. Lituania, de 24 de abril de 2008, donde dos jóvenes fueron muertos por los disparos de la policía al intentar detener un coche en su huida, en Celniku v. Grecia, de 5 de julio de 2007, en el que la víctima fue privada de su vida durante su arresto porque no levantó las manos, sino que hizo un gesto que parecía indicar que se disponía a sacar un arma de su impermeable (aunque el Tribunal encontró que el uso de la fuerza estaba justificado, no hubo una adecuada organización policial ni tampoco una investigación oficial efectiva), o en Leonidis v. Grecia, de 8 de enero de 2009. Cabe reseñar de modo especial el caso Khatsiyen v. Rusia, de 17 de enero de 2008, donde el Tribunal ha considerado contraria al art. 2, tanto por razones de fondo como en su dimensión procedimental (carencia de investigación efectiva), la muerte de varias personas chechenas por disparos de un helicóptero ruso.

Es claro que la valoración minuciosa por parte del TEDH de todas las circunstancias que rodean las operaciones militares o policiales en las que resulta muerto alguien, intencionadamente o no, es una postura activista y garantista, con todas sus ventajas (arrojar algo de luz sobre la excepción turca y/o los excesos británicos en la lucha contra el IRA, por ejemplo), pero también con sus problemas, porque, evidentemente, el Tribunal se convierte en un juez de los hechos. En este sentido, volviendo al caso McCann, hay una importante opinión discrepante de nueve jueces que llama la atención precisamente sobre este aspecto de la cuestión. ${ }^{22}$ El asunto McCann ya había sido decidido ante un jurado y el Gobierno británico sostenía que el TEDH debería conceder "un peso substancial" a su veredicto exculpatorio "salvo que hubiera algún indicio de que dicho veredicto fuera ilícito" porque el jurado fue el único órgano bien situado para apreciar las circunstancias fácticas concurrentes en el caso. El Tribunal respondió que, ciertamente, "el jurado tuvo el beneficio de oír a los testigos de primera mano", pero "no aportó razones para la conclusión que alcanzó". Por otro lado, el estándar que empleó el jurado fue si la acción de los soldados había estado razonablemente justificada en las circunstancias concurrentes, y no el más estricto de si era "absolutamente necesario" bajo el art. 2.2 del Convenio. Por ello el Tribunal reivindica

22 Junto con una distinta valoración del caso, ya que, a su juicio, los militares tuvieron que adoptar decisiones necesariamente con datos incompletos. No se puede enjuiciar un hecho ex post facto porque en caso contrario se otorga una ventaja táctica a los criminales frente a las fuerzas de seguridad. 
el derecho a realizar su propio juicio. Hay aquí un buen ejemplo de una distinta legalidad penal "nacional" y "europea" en estos casos.

Pero la Sentencia McCann es más influyente y perdurable aún porque acuña otro estándar más general cual es el de la dimensión procedimental del derecho a la protección de la vida, un estándar que va a permitir al Tribunal condenar casi siempre a los Estados demandados por violación del derecho a la vida de personas sobre las que no se tuvo constancia, más allá de toda duda razonable, que hubieran sido asesinadas por las fuerzas de seguridad, pero sobre las que el Estado tenía un deber general de protección, de modo que éste debía haber realizado "una efectiva investigación oficial" pero no lo hizo. La doctrina McCann apenas profundiza en este concepto que tanto juego posterior daría en la labor del Tribunal porque en el caso sí hubo una "investigación oficial efectiva", pero lo apunta de este modo en el párrafo 161: "Una prohibición general legal de causar la muerte arbitrariamente por parte de los agentes de un Estado será inefectiva si no existiera un procedimiento para revisar la corrección del uso de la fuerza letal por las autoridades estatales. La obligación de proteger el derecho a la vida bajo el art. 2, leída conjuntamente con el deber general del Estado, según el art. 1, de asegurar a todos dentro de su jurisdicción los derechos y libertades definidos en la Convención, requiere en consecuencia que exista alguna forma de investigación oficial efectiva cuando los individuos hayan perdido la vida como resultado del uso de la fuerza por, entre otros, agentes del Estado".

Los párrafos citados de la Sentencia McCann se han citado profusamente después. En la mayoría de los casos, el Tribunal ha condenado a las autoridades nacionales respectivas porque no realizaron una "efectiva investigación oficial". En no pocos, se demostró que las fuerzas de seguridad habían asesinado o habían hecho desaparecer a disidentes políticos. El TEDH ha explicitado el concepto de "efectiva investigación oficial" en tres escenarios problemáticos: ${ }^{23}$ (a) uso desproporcionado de la fuerza por agentes públicos; (b) desaparecidos tras su detención y (c) torturas y muerte de personas en dependencias policiales.

A) Uso desproporcionado de la fuerza por parte de agentes de la autoridad, acompañado de carencia de investigación oficial efectiva, ha estimado, por ejemplo, el TEDH en casos como los siguientes. En el Caso Güleç v. Turquía, de 28 de julio de 1998, se juzga la muerte de un niño, a la salida del colegio, que es disparado en el curso de una manifestación del PKK violentamente disuelta. El Tribunal aprecia violación del art. 2 por la policía turca, aunque no tiene constancia de quién mató realmente al niño, porque la fuerza usada para disolver la manifestación (con armas de fuego y no con balas de goma, cañones de agua y otros métodos antidisturbios ${ }^{24}$ ) "no fue

23 Son numerosas las analogías que podrían establecerse, también en este punto, entre la jurisprudencia del TEDH y de la Corte Interamericana de Derechos Humanos desde su importante Sentencia Velásquez Rodríguez (contra Honduras), de 24 de abril de 1986.

24 Lo cual, apostilla el Tribunal, "es incomprensible e inaceptable porque la provincia de Sirnak es una región donde se ha declarado el estado de emergencia". 
absolutamente necesaria dentro del significado del art. 2". En el Yasa v. Turquía, de 2 de septiembre de 1998, el TEDH precisa, en relación con el requisito de la investigación oficial efectiva, que "no se contrae sólo a los casos en los que se establezca que la muerte ha sido causada por un agente estatal", sino que basta que las autoridades fueran informadas de un asesinato..$^{25}$ En Jordan v. Reino Unido, de 4 de mayo de 2001, el Tribunal realiza un magnífico resumen de los requisitos que debe reunir la investigación oficial efectiva sobre cualquier alegación de muerte injustificada a manos de agentes estatales: ${ }^{26}$

(1) Las personas responsables de la misma deben ser "independientes" de aquellas otras implicadas en los hechos. Esto implica "no sólo una carencia de conexión jerárquica e institucional, sino también una independencia práctica" ${ }^{27}$

(2) La investigación ha de ser también "efectiva", en el sentido de ser capaz de "conducir a la determinación de si la fuerza usada en tales casos estaba o no justificada dadas las circunstancias del caso, y a la identificación y castigo de los responsables". Ésta no es, precisa el Tribunal, "una obligación de resultado, sino de medios". Las autoridades "deben haber adoptado las medidas razonables disponibles para asegurar la prueba relativa al incidente, incluyendo, inter alia, el testimonio de los testigos presenciales, la prueba forense y, cuando sea apropiado, una autopsia que proporcione un completo informe de las lesiones y un análisis objetivo de las pruebas clínicas, incluyendo la causa de la muerte". A dvierte el Tribunal que "cualquier deficiencia en la investigación que debilite su capacidad para establecer la causa de la muerte o la persona o personas responsables correrá el riesgo de caer fuera de este estándar".

(3) La investigación deber realizarse con "prontitud", aun admitiendo que "hay muchos obstáculos y dificultades que pueden impedir el avance de una investigación en una situación particular". Sin embargo, una "respuesta rápida por la autoridades investigando el uso de la fuerza letal podría generalmente ser vista como esencial para mantener la confianza pública en la adherencia al rule of law y para prevenir cualquier apariencia de colisión o tolerancia (del Gobierno) con actos ilegales".

(4) Por las mismas razones, debe existir "un elemento suficiente de escrutinio público de la investigación y sus resultados" para "asegurar la responsabilidad en la práctica tanto como en la teoría". El grado de escrutinio público "podrá variar según los casos", pero en todos ellos "el pariente más cercano de la víctima deberá estar implicado en los procedimientos necesariamente para garantizar sus intereses legítimos" ${ }^{28}$

25 El TEDH aprecia violación porque no hubo esa investigación en el caso, tras haber sido denunciado el asesinato del tío del demandante hacía más de cinco años.

26 La doctrina Jordan suele, por ello, también citarse en todos los casos en los que se alude a la necesidad de esa investigación oficial efectiva.

27 El Tribunal pone como ejemplo en contrario el citado caso Ergi, en el que el fiscal del caso mostró una sumisión excesiva a la información proporcionada por los agentes implicados en el incidente.

28 En algunos casos relativos a Turquía no se permitió a estos familiares acceder a la investigación o no se les informó de sus resultados: Güleç, de 28 de julio de 1998 u Ögur, de 20 de mayo de 1999. 
A plicados estos criterios al asunto Jordan (un chico de Irlanda del Norte muerto por un disparo de policía), el Tribunal concluyó que la investigación oficial del caso no había sido rápida, ni independiente, ni había tenido escrutinio público, ni se había informado de la misma a los familiares de la víctima. A idéntico resultado llega el TEDH en los semejantes casos McKerr v. Reino Unido, de 4 de mayo de 2001, Kelly y otros v. Reino Unido, de la misma fecha y Finucane v. Reino Unido, de 1 de julio de 2003. En Shanagahan v. Reino Unido, también de 4 de mayo de 2001, se produce la variante respecto de los casos anteriores de que no se conocía con certeza quién disparó y mató al hijo de la demandante, pero el resultado, gracias a la doctrina de la necesidad de la investigación oficial efectiva, es el mismo, habría habido vulneración del art. 2 del Convenio también en este caso por su carencia. En todos asuntos, el TEDH lanzó un aviso a las autoridades británicas porque las deficiencias observadas en todos ellos se referían al peculiar sistema de instrucción penal aplicable, que no superaba las exigencias descritas aportadas por el Tribunal. Es destacable cómo el Tribunal ha condenado a Reino Unido en cinco Sentencias de 27 de noviembre de 2007: Brecknell; Reavey; 0'Dowd; McCartney y McGrath, por casos semejantes, católicos asesinad os por unionistas en Irlanda del Norte (a veces en sus propios domicilios, a la familia entera) sin que se produjera una investigación oficial efectiva y, sobre todo, independiente, ya que la propia Policía parecía estar implicada en los hechos. En Ramsahai y otros v. Holanda, de 15 de mayo de 2007, el Tribunal ha condenado a Holanda por la carencia de una investigación oficial efectiva en el caso de la muerte de una persona por disparo policial durante su arresto ya que la investigación no fue en algunos aspectos ni adecuada (se habrían producido algunas lagunas en la investigación) ni independiente (en algunas fases de la misma la supervisión procedió de la misma oficina policial a la que pertenecían los dos policías implicados).

No siempre el TEDH ha apreciado violación del art. 2 en este tipo de casos por insuficiente investigación oficial efectiva. En el Caso Sabuktekin v. Turquía, de 19 de marzo de 2002, por ejemplo, no lo hizo. Pero es más bien la excepción que confirma la regla. ${ }^{29}$

En esta línea de casos, McShane v. Reino Unido, de 28 de mayo de 2002, tiene algún interés adicional. La demandante alegaba que su marido, que salía de un pub en Londonderry a la 1.30 de la noche, había muerto por las fuerzas de seguridad británicas (concretamente, en el curso de una revuelta había sido atropellado más o menos accidentalmente por una tanqueta con capacidad para derribar barricadas), lo cual constituía un uso de la fuerza desproporcionado y, además, no se había producido

29 En Kaya v. Turquía, de 28 de marzo de 2000 se condena, como, entre otros, en Onen v. Turquía, de 14 de mayo de 2002, en Ulkuekinçi v. Turquía, de 16 de julio de 2002, en Tepe v. Turquía, de 9 de mayo de 2003, Akdenit v. Turquía, de 31 de mayo de 2005, Hamiyet Kaplan y otros v. Turquía, de 8 de 13 de septiembre de 2005, Kanlibas v. Turquía, de 8 de diciembre de 2005, en Gömi y otros v. Turquía, de 21 de diciembre de 2006, en Anter y otros v. Turquía, de 19 de diciembre de 2006, en Ataman v. Turquía, de 27 de abril de 2006, Biskin v. Turquía, de 10 de enero de 2006, Mordeniz v. Turquía, de 10 de enero de 2006, o en Kamil Uzun v. Turquía, de 10 de mayo de 2007. 
una investigación oficial efectiva. El Tribunal estima que la expresión "recurso a la fuerza" del art. 2 es aplicable no sólo al uso de armas o de violencia física, sino también, "sin distorsión del lenguaje", al uso de un vehículo armado como el que atropeIló al Sr. M cShane. En este caso se trata de un soldado al que se le dan órdenes de usar un vehículo armado pesado durante una revuelta para derribar una barricada que están usando civiles como escudo, por lo que debe ser considerado como parte de una operación de las fuerzas de seguridad por la que el Estado es potencialmente responsable según el art. 2 del Convenio. El Tribunal no llega a establecer la responsabilidad del Estado porque cuestiones fácticas centrales, como, por ejemplo, la velocidad a la que iba el vehículo, eran controvertidas, pero analiza el caso desde los requisitos de la investigación oficial efectiva, concluyendo que hubo violación del art. 2 (porque la investigación no fue independiente, ni comenzó pronto, etc.). Por esta vía ha podido el Tribunal condenar violaciones del derecho a la protección jurídica de la vida que no hubieran podido lograrse de otro modo.

Un supuesto específico de uso desproporcionado de la fuerza policial con resultado de muerte abordado por el Tribunal ha sido el de los casos de inmovilización de una persona en condiciones peligrosas para la vida. En Scavuzzo-Hager y otros v. Suiza, de 7 de febrero de 2006, el Tribunal falló que la muerte de una persona tras su arresto por la policía cantonal no había sido consecuencia de un uso desproporcionado de la fuerza, ya que la víctima tenía un precario estado de salud por su adicción a las drogas, pero sí apreció lesión del art. 2 del Convenio en su dimensión procedimental en la medida en que no hubo una investigación oficial efectiva de la relación de causalidad entre la inmovilización policial y la muerte del sujeto. Esta Sentencia es importante porque establece los dos criterios que han de tenerse en cuenta en los supuestos de inmovilización policial de una persona en condiciones peligrosas: (1은 La relación de causalidad entre la fuerza empleada y la muerte en cuestión. (2º El cumplimiento o no del deber positivo de protección de la vida de las personas a las que se arresta, que implica no una carga insoportable o excesiva, sino el deber de dispensar con diligencia cuidados médicos para prevenir un desenlace fatal. Pues bien, así como en el caso Scavuzzo-Hager y otros, el Tribunal consideró que ni se pudo probar la relación de causalidad entre el arresto y la muerte del sujeto, ni los policías descuidaron el deber de protección de la vida del arrestado, en la Sentencia Saoud v. Francia, de 9 de octubre de 2007, sí encontró que la inmovilización practicada por la policía contra un ciudadano francés de origen tunecino que padecía una grave enfermedad psiquiátrica, en pleno brote de violencia contra su familia, fue la causa de su muerte y constituyó, en consecuencia, una violación sustantiva del art. 2 del Convenio. El Tribunal aplica los dos criterios de la Sentencia Scavuzzo-Hager a este caso, concluyendo que, aunque el uso de la fuerza estaba en principio justificado para detener los actos violentos del sujeto, el mantenimiento en el suelo del sujeto produjo, según los expertos médicos, su muerte por asfixia lenta. A demás, los policías no le prestaron el debido cuidado médico porque ni siquiera recibió un examen médico superficial. 
B) El caso de los desaparecidos tras su detención por fuerzas de seguridad. Se cuentan en este desgraciado apartado numerosas Sentencias de condena a Turquía, ${ }^{30}$ aunque también Rusia tiene el dudoso honor de haber sido condenado por este motivo. ${ }^{31}$ La doctrina principal es establecida en la primera Sentencia, caso Çakici (completada por la Sentencia Timurtas): como la persona desaparecida debe ser presumida muerta tras su detención por las fuerzas de seguridad turcas, el Tribunal entiende que se desencadena la responsabilidad del Estado por su muerte y, por tanto, debe ofrecer una explicación plausible sobre la suerte del detenido. De no hacerlo, se puede presumir, considerando las circunstancias del caso, que el detenido ha muerto estando bajo custodia, y, en consecuencia, se produce una violación automática del art. 2 del Convenio (como ocurre en todos los casos). A este respecto, "el periodo de tiempo que ha transcurrido desde que la persona fue detenida, aunque no decisiva en sí misma, es un factor relevante para ser tenido en cuenta". De modo que "cuanto más tiempo transcurra sin tener noticias, mayor probabilidad habrá de que esté muerto" (Sentencia Timurtas).

Esta presunción de desaparición tras arresto policial como equivalente a asesinato fue discutida por el juez turco del Tribunal en su voto discrepante a la Sentencia Timurtas, pero no ha impedido que la opinión de la mayoría se impusiera y consolidara. En todo caso y a mayor abundamiento, el Estado debe también realizar la investigación oficial efectiva en los términos expuestos (lo que tampoco se hizo en ninguno de los casos, obviamente). Esto permitió condenar a Turquía en la demanda que le planteó Chipre por las personas de origen griego que desaparecieron en la parte turca de la isla. El Tribunal no pudo establecer, más allá de toda duda razonable, por falta de pruebas, que los desaparecidos hubieran sido asesinados por las fuerzas turcas o turco-chipriotras, pero dado que sí había pruebas de que muchas personas desaparecidas fueron detenidas por estas fuerzas, que eso ocurrió en un periodo en el que las operaciones militares venían acompañadas de arrestos y asesinatos a gran escala (sobre todo en los meses del verano de 1974), y que, por tanto, la situación era "amenazante para la vida", el Estado demandado debía haber realizado una investigación oficial efectiva, que nunca hizo, dirigida a clarificar el paradero de los desaparecidos. Otro buen ejemplo de cómo el estándar de la investigación oficial efectiva avanza la barrera de la protección desde las acciones de las fuerzas de seguridad a sus (significativas) omisiones. Es, sin duda, un expediente inteligente porque dado que casi con total seguridad la policía y/o el ejército asesinaron a disidentes (aunque no se pueda en algunos casos probar), no podrán explicar convincentemente qué hicieron con ellos, con lo cual si de verdad les asesinaron no podrán superar el requisito de la

30 Çakici (8 de julio de 1999), Ertak (9 de mayo de 2000), Timurtas (13 de junio de 2000), Tas (14 de noviembre de 2000), Demiray (21 de noviembre de 2000), Cicek (27 de febrero de 2001), Chipre (10 de mayo de 2001), Akdeniz y otros (31 de mayo de 2001), Ausar (10 de julio de 2001), Bilgin (17 de julio de 2001), Orak (14 de febrero de 2002), Orhan (18 de junio de 2002), o Diril, de 19 de octubre de 2006.

31 Imakayeva v. Rusia, de 9 de noviembre de 2006, o Luluyev v. Rusia, de 9 de febrero de 2007. Ambos casos se refieren a secuestros por personal militar con posterior asesinato; en ninguno de ellos se produjo una investigación oficial efectiva. Ver también: Bazorkina v. Rusia, de 27 de julio de 2006. 
investigación efectiva. En otras palabras, el requerimiento de una "investigación oficial efectiva" es una magnífica trampa para asesinos oficiales.

C) Un último supuesto, cercano al anterior y resuelto por los mismos criterios, es el de la tortura y muerte de personas en dependencias policiales. Las sentencias en este ámbito suelen referirse a Bulgaria: (entre otras, Velikova (18 de mayo de 2000) y Anguelova (13 de junio de 2002), y a Turquía Salman (27 de junio de 2000), Tanli (10 de abril de 2001) y A ktas (24 de abril de 2003). En esta última Sentencia, el Tribunal reitera enfáticamente la necesidad de que los Estados "deben proporcionar todas las facilidades para hacer posible un examen efectivo de las demandas". Porque "es inherente a procedimientos relativos a causas de esta naturaleza, donde un particular acusa a agentes de un Estado de violar derechos del Convenio, que, en ciertos ámbitos sólo el Estado demandado tenga acceso a información capaz de corroborar o refutar tales alegaciones". ${ }^{32}$ Por otro lado, el Tribunal ha venido sosteniendo que las personas detenidas están "en una situación vulnerable" y las autoridades nacionales están por ello obligadas especialmente a protegerlas. Consecuentemente, "cuando un individuo es puesto bajo custodia policial y después se le lesiona, incumbe al Estado aportar una explicación plausible de cómo fueron causadas las heridas" y "la obligación de las autoridades de responsabilizarse del trato a una persona detenida es particularmente astringente cuando el individuo muere o desaparece" (Sentencia Aktas).

Aunque guarda escasas coincidencias con estos casos, quizás no esté de más recordar el Caso Díaz Ruano v. España, de 26 de abril de 1994, que concluyó en un acuerdo amistoso entre nuestro país y el demandante. La Comisión había concluido que no había habido violación del art. 2 del Convenio. Se trata del caso de un detenido que muere accidentalmente del disparo de un policía durante un interrogatorio en una comisaría de Gran Canaria. El policía que disparó fue exonerado de culpabilidad por legítima defensa por el Tribunal Supremo español.

Un factor significativo a tener en cuenta en este escenario es el de la discriminación a minorías raciales, aunque hay un "antes" y un "después" marcado por el memorable voto particular del magistrado Bonello en la Sentencia Anguelova contra Bulgaria de 13 de septiembre de 2002 y la posterior Sentencia Nachova y otros contra Bulgaria, de 6 de julio de 2005. Antes del caso Nachova, en los asuntos Velikova contra Bulgaria, de 18 de mayo de 2000 y Anguelova contra Bulgaria, de 13 de septiembre de 2002, el Tribunal se enfrentó a las alegaciones de móviles racistas en las muertes de algunas personas gitanas en dependencias policiales, argumentando del mismo modo: exigiendo una prueba de tales actitudes "más allá de una duda razonable". Un estándar de prueba tan astringente condujo, sin remisión, a que el Tribunal no apreciara discriminación racial (en conexión con la protección jurídica de la vida del art. 2 del Convenio -que sí se consideraba lesionado). Y eso que el Tribunal, en ambos casos,

32 Precisamente en el caso A ktas el Tribunal observa obstáculos a la investigación opuestos por el Estado demandado (entre otras cosas, quizás, porque el Tribunal considera probado que el señor Aktas fue asesinado mientras estaba prisionero por algún tipo de técnica que le produjo asfixia mecánica. 
observó que la alegación por los demandantes del asesinato por móviles racistas "se basaba en razones serias" y que el Estado demandado, Bulgaria, no había ofrecido una explicación plausible a la muerte de las víctimas y a la omisión en la investigación posterior de ciertos aspectos que podrían haber iluminado los hechos.

A la Sentencia Anguelova le acompaña, como ya dije, un voto discrepante del magistrado Bonello de gran estatura técnica, ${ }^{33}$ que invita al Tribunal a "replantear" de modo "radical y creativo" su aproximación a la materia y le propone diversas vías: la técnica de la inversión de la carga de la prueba, ${ }^{34}$ o la estimación de la violación del derecho si el Gobierno de que se trate no proporciona la información a la que sólo él tenía acceso, ${ }^{35}$ o la presunción de que cuando un miembro de un grupo desventajado sufre daño en un asunto donde las tensiones raciales son altas y la impunidad de los ofensores estatales epidémica, la carga de la prueba de que el suceso no fue étnicamente provocado debería corresponder al Estado. Y, por supuesto, habría también violación del art. 14 (en relación con el art. 20 el 3) cuando el Estado no investigue adecuadamente los móviles racistas del ataque a la vida o la integridad física y moral

33 Comienza observado que es "inquietante" que el Tribunal Europeo en sus más de cincuenta años de existencia no haya encontrado un solo caso de violación de la protección jurídica de la vida (art. 2) 0 frente a la tortura o los tratos inhumanos y degradantes (art. 3) inducidos por móviles racistas. "Leyendo los anales de la jurisprudencia, un observador no informado creerá que Europa carece de cualquier sospecha de racismo, intolerancia o xenofobia". La Europa proyectada por esa jurisprudencia "es un cielo de fraternidad étnica", en el cual "las gentes de los más diversos orígenes conviven sin preocupación, prejuicio o discriminación". Constata también Bonello que de modo regular el Tribunal conoce casos en los que los miembros de una minoría vulnerable son privados de su vida o sufren malos tratos, pero ni una sola vez ha encontrado relación con su etnicidad: "kurdos, musulmanes y gitanos son una y otra vez asesinados, torturados o maltratados, pero el Tribunal no está convencido de que su raza, color, nacionalidad o lugar de origen tengan algo que ver con ello". Con ironía, remata su idea: "el infortunio visita puntualmente a los grupos minoritarios en desventaja, pero sólo como resultado de una feliz coincidencia". La luz roja se enciende ahora, de modo particular, con las sistemáticas violaciones de los artículos segundo y tercero del Convenio de los gitanos en Bulgaria (y no sólo por los casos que finalmente llegan ante el Tribunal, también trae a colación Bonello informes de Amnistía Internacional, de Naciones Unidas y del propio Consejo de Europa sobre el particular).

Bonello sitúa la raíz de este "escape de la realidad" en la regla probatoria de la "duda más allá de lo razonable". A su juicio, el Tribunal, que, como regla general, debe hacer los derechos "practicables y efectivos y no teóricos o ilusorios" (Artico contra Italia, de 13 de mayo de 1980), no puede utilizar un estándar probatorio equivalente al que en un Estado se requiere para obtener una condena penal. Esta equivalencia convierte en "ilusoria, ineficaz e inalcanzable" a la protección contra la discriminación. Bonello sostiene que tanto la Corte Interamericana de Derechos Humanos como el Tribunal Supremo federal de los Estados Unidos han establecido estándares mucho más razonables. La primera ha afirmado (en Velásquez Rodríguez contra Honduras, de 29 de julio de 1988) que "la protección internacional de los derechos humanos no debe confundirse con la justicia penal" y el Tribunal norteamericano, como es conocido, una vez que admite la prima facie discriminatoria ofrecida por el demandante (los indicios suficientes de discriminación de nuestro Tribunal Constitucional), invierte la carga de la prueba, de modo que corresponde al demandado demostrar que su práctica no es discriminatoria.

34 “Una técnica que el Tribunal ha adoptado con éxito cuando la alternativa habría hecho la búsqueda de la verdad imposible", como por ejemplo en los casos de desaparición de detenidos una vez conducidos a dependencias policiales, en los que corresponde al Estado ofrecer una explicación satisfactoria.

35 De modo semejante a la protección "procedimental" que el Tribunal ha creado en relación con la protección jurídica de la vida o frente a las torturas y tratos inhumanos. 
del miembro de una minoría étnica (de modo semejante a como sucede en relación con los derechos de los arts. 2 y 3 del Convenio). Es decir, Bonello propone la acuñación judicial de una dimensión procedimental de protección de la prohibición de discriminación, semejante a la que el Tribunal ha creado en relación con los derechos a la vida y a la integridad física y moral.

Pues bien, el Tribunal Europeo ha hecho suyas las propuestas del magistrado Bonello a partir de la capital Sentencia Nachova y otros contra Bulgaria, de 6 de julio de 2005, en la que afirma que en los casos de privación de la vida en que se alegue prejuicio racista las autoridades estatales han de llevar a cabo "una investigación efectiva" sobre esta conexión; $y$, más concretamente, tienen "el deber adicional de adoptar las medidas razonables para desenmascarar cualquier motivación racista en un incidente que implique el uso de la fuerza por los agentes estatales". En estos casos, "la carga de probar que no ha habido discriminación corresponde a las autoridades nacionales demandadas"; particularmente en casos de violencia racista, "el gobierno debe probar la ausencia de una actitud subjetiva concreta por parte de las personas afectadas". ${ }^{36}$ Añade que la "violencia racial es una ofensa particular a la dignidad humana que, a la vista de sus peligrosas consecuencias, requiere por parte de las autoridades de una vigilancia especial y una reacción vigorosa". En consecuencia, "las autoridades estatales deben usar todos los medios a su alcance para combatir el racismo y la violencia racista, reforzando una comprensión de la democracia como una sociedad en la que la diversidad no es percibida como una amenaza, sino como una fuente de riqueza". Nachova es una Sentencia en la que, por fin, el Tribunal se toma en serio la prohibición de discriminación del art. 14 del Convenio de Roma respecto de la violencia racial.

La doctrina Nachova es reiterada por el Tribunal en todos los casos semejantes posteriores: Bekos y Koutropoulos contra Grecia, de 13 de diciembre de $2005^{37}$ y Ognyanova y Chocan contra Bulgaria, de 23 de febrero de 2006. ${ }^{38}$

\section{LAS DECISIONES SOBRE EL FINAL Y EL COMIENZO DE LA VIDA: SUICIDIO ASISTIDO Y ESTATUTO JURÍDICO DEL FETO}

La cuestión de si el art. 2 del Convenio ampara de algún modo el suicidio asistido ha sido zanjada negativamente de plano y por unanimidad por el Tribunal en el famoso

36 El Tribunal concluyó que se había lesionado el art. 14 en relación con el art. 2 porque las autoridades estatales no investigaron si los hechos podrían haber sido racialmente motivados.

37 Las autoridades no habrían adoptado todos los pasos para investigar si en el origen de los hechos (actos de brutalidad policial durante la detención de dos gitanos griegos) hubo prejuicio racial, por lo que habría habido violación del art. 3 (prohibición de malos tratos) en combinación con el art. 14.

38 La víctima, un gitano, había muerto al caer desde una ventana de una comisaría búlgara. El Tribunal aprecia una violación del art. 2 del Convenio, pero no del art. 14 en este caso, puesto que, aunque cita la doctrina Nachova, a diferencia de los otros casos, no figura en el asunto ninguna concreta indicación de que las actitudes racistas jugaran algún papel en los hechos, ni los demandantes aportaron un solo dato en este sentido. 
Caso Pretty v. Reino Unido, de 29 de abril de 2002. La demandante era una mujer de 43 años con una enfermedad neuro-degenerativa de las células motoras dentro del sistema nervioso central que, en el momento de presentar la demanda, estaba paralizada de cuello para abajo, no podía casi hablar y su esperanza de vida no era superior al año (de hecho, poco después falleció de forma natural), aunque conservaba intacta su capacidad intelectual. No existía ningún tratamiento médico que pudiera frenar la progresión fatal de la enfermedad. En Gran Bretaña, como en España, el auxilio al suicidio está tipificado penalmente. Pues bien, la Sra. Pretty se dirigió al responsable de la acusación pública inglesa, el Director of Public Prosecutions solicitando que no abriera diligencias contra su esposo si éste le ayudara a suicidarse según su propio deseo. La solicitud fue desestimada y el asunto se trasladó a los tribunales, donde finalmente la House of Lords confirmó la negativa porque aquel órgano no puede negarse a perseguir un delito. El Tribunal británico dijo no ser "un cuerpo legislativo, ni un árbitro ético". De modo que el asunto se trasladó a Estrasburgo. Los argumentos en relación con el art. 2 del Convenio de la demandante son tres:

(1ㅇ) Permitirla ser asistida en el suicidio no lesionaría el art. 2, pues de otro modo los países europeos donde el suicidio asistido no es ilegal estarían violando tal disposición. A esto contesta el Tribunal que no le corresponde en ese momento determinar si la legislación de otros Estados desconocen o no la obligación de proteger el derecho a la vida.

(2) No son aplicables otros casos a éste, en especial, el resuelto por el TEDH, Keenan v. Reino Unido, de 3 de abril de 2001 (las autoridades penitenciarias tienen la obligación de evitar que los internos se suiciden), porque Keenan no tenía, por su enfermedad mental, capacidad para tomar una decisión racional para acabar con su vida. Por su parte, el Gobierno británico recuerda la decisión de la Comisión en $\mathbf{X}$ v. A lemania, de 9 de mayo de 1984, en la que sostuvo que la alimentación forzosa de un prisionero en huelga de hambre era legítima. ${ }^{39} \mathrm{El}$ Tribunal no contesta explícitamente a este argumento, pero sí lo hace implícitamente a no utilizar ningunos de los dos casos anteriores señalados como parámetro de comparación con el asunto ahora en examen.

(3) El argumento principal de la demandante fue que el art. 2 protege el derecho a la vida y también el derecho a elegir si se sigue o no viviendo. Protegería el derecho a la vida y no la vida misma, y lo haría frente al Estado y otros particulares, pero no contra uno mismo. Esta idea es rebatida radicalmente por el Tribunal. Después de reiterar la doctrina conocida sobre la "preeminencia" del art. 2, sin cuyo ejercicio "ninguno de los demás derechos y libertades de la Convención serían posibles", y la obligación que se deriva para el Estado de proteger la vida adoptando medidas adecuadas para salvaguardar la vida de aquellos que se hallen bajo su jurisdicción, el Tribunal resume el énfasis de su jurisprudencia sobre el art. 2 en "la obligación del

39 Un caso similar a los resueltos por el Tribunal Constitucional español, en el mismo sentido, mediante Sentencias 120/1990 y 137/1990, de 19 de julio y 11/1991, de 17 de enero, casos de la huelga de hambre de los presos del grupo terrorista de los GRAPO. 
Estado de proteger la vida". Pues bien, sostiene que "el Tribunal no está persuadido de que el derecho a la vida garantizado por el art. 2 pueda ser interpretado como que contiene una dimensión negativa". A diferencia de las libertades, como la de asociación del art. 11, que comprende la libertad de asociarse o de no hacerlo, "que implican alguna medida de elección sobre cómo se ejercitan", el art. 2 "es enunciado en diferentes términos". No se refiere, afirma el Tribunal, "a lo que una persona elige hacer con su vida". Esto, en su caso, debería reconocerse en otros preceptos del Convenio o en otros textos jurídicos. "Pero el art. 2 no puede, sin una distorsión del lenguaje, ser interpretado como si otorgara el derecho diametralmente opuesto, el derecho a morir; ni puede crear un derecho de autodeterminación en el sentido de conferir a un individuo la facultad de elegir morir más que vivir".

El Tribunal decide, pues, no zanjar un asunto como éste, tan problemático y tratado de modo diverso en los diferentes ordenamientos nacionales. Bien es cierto que hay un importante y reciente documento al que se remite, la Recomendación 1418/1999 de la Asamblea Parlamentaria del Consejo de Europa, cuyo párrafo noveno reconoce que el deseo de un enfermo terminal de morir "nunca puede constituir una demanda legal para morir a manos de otra persona" y que tampoco "puede por sí mismo constituir una justificación legal para evitar las acciones penales derivadas de la causación de la muerte".

De manera mucho más modesta se ha planteado la cuestión de la compatibilidad con el art. 2 de sistemas legales que permitan el aborto en ciertos casos. Como es sabido, no hay Sentencia directa del Tribunal en este sentido y tan sólo existen, como criterio interpretativo, varias decisiones de la Comisión. Entre ellas, la más importante es la decisión X v. Reino Unido, de 13 de mayo de 1980, en la cual el recurrente, marido de una mujer en proceso de abortar, lamentaba que el derecho inglés no reconociera al padre ningún derecho de prohibir el ejercicio del aborto. La Comisión, tras sostener que el término "toda persona" del art. 2 no significa que incluya al niño no nacido se planteó tres preguntas: (1 $\left.{ }^{a}\right)$ Si el art. 2 reconoce al nasciturus un derecho absoluto a la vida. (2 $\left.{ }^{a}\right) \mathrm{Si}$ el feto no tiene ningún derecho. (3a) Si, por el contrario, el feto goza de algunos derechos limitados. En su decisión, la Comisión ha concluido que no es posible reconocer un derecho absoluto a la vida del feto cuando pueda causar daños a la vida de la madre. En cuanto a lo demás no se ha pronunciado porque en el caso en examen el aborto era necesario para evitar consecuencias graves para la salud de la madre. Nos encontramos, pues, con otro ambiguo y salomónico razonamiento sobre tan delicado asunto que no por ello me resulta totalmente insatisfactorio. ${ }^{40}$

40 De la interpretación de la Comisión se deduce, a mi juicio, la plena compatibilidad con el Convenio del denominado "aborto terapéutico", que se produce en el escenario típico del conflicto de bienes. El aborto producto de una violación también podría incluirse sin demasiado esfuerzo en este ámbito, según creo. Mayores problemas podrían producirse con el aborto eugenésico y, sobre todo, con un sistema que no fuera de indicaciones sino directamente de plazos. Esta decisión de la Comisión fue invocada por el A bogado del Estado para oponerse al recurso previo de inconstitucionalidad contra la reforma del Código Penal español que despenalizó este tipo de abortos y el Tribunal Constitucional, en su Sentencia 53/1985 (f. jco. 6ㅇ), la utilizó para recordar que la Comisión excluyó que "el feto pudiera tener un derecho a la vida de carácter absoluto". 
No directamente sobre la cuestión del aborto, sino sobre el estatuto jurídico del feto humano ha recaído la relevante Sentencia Vo v. Francia, de 8 de julio de 2004. La demandante, una ciudadana francesa llamada Thi-Nho Vo, alegaba que las autoridades judiciales nacionales habían violado el art. 2 del Convenio porque la conducta del médico que fue responsable de la muerte de su feto de seis meses in utero no se calificó como un homicidio intencional. ${ }^{41}$ La demanda sostenía que el término "toda persona" del art. 2 incluía a todo ser humano, también a los concebidos pero todavía no nacidos y, por tanto, las legislaciones de los Estados debían asegurar la protección de éstos tipificando penalmente el homicidio involuntario, incluso aunque, en ciertos casos, permitieran el aborto. El asunto en litigio era, pues, si la ausencia de una respuesta criminal dentro del sistema jurídico francés para castigar la destrucción involuntaria de un feto constituía un fallo estatal en la protección del derecho a la vida en el sentido del art. 2 del Convenio. El Tribunal recuerda, en primer lugar, las escasas decisiones anteriores, tanto suyas como, sobre todo, de la Comisión, concluyendo que el nasciturus no ha sido visto por ellos como una "persona" directamente protegida por el art. 2 del Convenio y que aunque el no-nacido tuviera un "derecho" a la "vida", estaría implícitamente limitado por los derechos de la madre, aunque tampoco se ha excluido la posibilidad de que en ciertas circunstancias se pueda extender la protección al niño no-nacido. ${ }^{42}$ Es preciso que exista un equilibrio entre los intereses de la madre y la necesidad de asegurar protección al no-nacido. ${ }^{43}$ El Tribunal justifica su interpretación en "el claro deseo de establecer un equilibrio... respecto de las dimensiones jurídicas, médicas, filosóficas, éticas y religiosas a la hora de definir qué sea un 'ser humano' tomadas en cuenta por las distintas regulaciones del asunto en el ámbito de los Estados". La cuestión de cuándo comienza el derecho a la vida debe remitirse, declara el Tribunal, al margen de apreciación de los Estados por dos razones: primera, porque esta cuestión (el estatuto jurídico del embrión y del feto) no ha sido ni siquiera resuelta por los propios Estados y segunda, porque no existe un "consenso

41 El médico del Hospital General de Lyon cometió un error trágico pues confundió a la demandante con otra paciente llamada de modo semejante, Thi Thanh Van Vo, y, como consecuencia de su intervención, perforó el saco amniótico de la demandante, lo que produjo la muerte de su feto.

42 El Tribunal anota, ante todo, que, a diferencia del art. 4 de la Convención Americana de Derechos Humanos, el art. 2 del Convenio no prevé que el derecho a la vida debe protegerse, "en general, desde el momento de la concepción". El art. 2 CEDH guarda silencio sobre las limitaciones temporales del derecho a la vida y, en particular, no define qué cabe entender por "toda persona" cuya vida se protege por el Convenio y si el no-nacido tiene tal derecho. El aborto no es una de las excepciones expresamente enumeradas en el art. 2.2 CEDH, pero la Comisión ha expresado la opinión de que es compatible con el primer apartado del art. 2.1 CEDH para asegurar la salud y la vida de la madre (Decisión de la Comisión X v. Reino Unido, de 13 de mayo de 1980). Ahora bien, en el Informe de la Comisión Brüggemann and Scheuten v. Alemania, de 12 de julio de 1977), se dice que "el embarazo no puede verse como algo que pertenezca sólo a la esfera de la vida privada... pues la vida privada de la embarazada está directamente relacionada con el feto en desarrollo", de modo que "el art. 8.1 del Convenio no puede ser interpretado como que el embarazo y su terminación son, en principio, asuntos que afectan a la vida privada de la madre".

43 Decisión del TEDH Boso v. Italia, de 5 de septiembre de 2002. 
europeo"44 sobre la definición científica y jurídica del comienzo de la vida, aunque están empezando a recibir embriones y fetos alguna protección a la luz de los progresos científicos y las potenciales consecuencias de la investigación en ingeniería genética, procreación asistida y experimentación con embriones. Como mucho, "podría decirse que es una idea compartida entre los Estados que el embrión y el feto pertenecen a la raza humana". "La potencialidad de estos seres y su capacidad para llegar a ser personas (lo que les asegura protección en diversos Estados desde el punto de vista del derecho civil), requiere protegerles en nombre de la dignidad humana, sin necesidad de convertirlos en una "persona" con "derecho a la vida" a los efectos del art. 2 CEDH". Esta doctrina es semejante a la que ha empleado el Tribunal Constitucional español a partir de su Sentencia 53/1985 sobre el aborto (a su vez inspirada en la jurisprudencia de aquel momento del Tribunal Constitucional Federal alemán). En cualquier caso, continúa razonando el Tribunal Europeo, "no es deseable, ni posible, responder en abstracto a la cuestión de si un no-nacido es una persona a los efectos del art. 2 CEDH". Y mucho menos en el caso en examen, porque, incluso asumiendo que ese precepto fuera aplicable, el Estado francés no ha fallado a la hora de cumplir los requerimientos procedimentales de protección inherentes en el art. 2 CEDH. La demandante entendía que sólo una sanción penal cumpliría tales requerimientos, pero el Tribunal no comparte este punto de vista para el caso de las negligencias médicas. ${ }^{45} \mathrm{La}$ demandante disponía de una acción por daños ante los tribunales administrativos, que el Tribunal consideró como un "remedio efectivo" y, por tanto, incluso asumiendo que el art. 2 CEDH fuera aplicable en este caso, falló que no había habido violación de tal precepto. Cuatro votos particulares acompañaron la Sentencia, aunque sólo hubo dos discrepantes (los otros dos fueron concurrentes). ${ }^{46}$

44 El Tribunal observa que la Convención de Oviedo sobre Derechos Humanos y Biomedicina deliberadamente no da una definición del término "todos" porque no existe un acuerdo general sobre ello y deben ser los Estados miembros los que decidan en sede nacional qué debe entenderse. Algo semejante ocurre en el Protocolo Adicional sobre prohibición de la Clonación Humana y el borrador del Protocolo Adicional sobre Investigación Biomédica.

45 Según doctrina constante del Tribunal, en el campo específico de las negligencias médicas, "la obligación podría también satisfacerse proporcionando a las víctimas una acción ante los tribunales civiles, sola o en conjunción con acciones penales... medidas disciplinares también podrían ser consideradas".

46 Para el Juez COSTA, el art. 2 CEDH era plenamente aplicable. Según ROZAKIS (con el que coinciden CAFLISCH, FISCHBACH, LORENZEN y THOM ASSEN), sí existe un consenso europeo (ético y jurídico) sobre el hecho de que la vida un niño no nacido, aunque protegido en algunos de sus atributos, no puede equipararse a la vida post-natal protegida por el art. 2 CEDH (y, por tanto, lo entienden inaplicable al caso ). Por su parte, el Juez RESS considera que un remedio administrativo y no penal como el del caso en examen no proporciona al nasciturus (que sí estaría protegido por el art. 2 CEDH, aunque no fuera del mismo modo que los seres ya nacidos) una adecuada y efectiva protección contra la negligencia médica y, por consiguiente, habría habido una violación del art. 2 CEDH. MULONARI (al que se adhiere STRÁZNICKÁ) argumenta en un sentido semejante que el art. 2 era aplicable y que habría sido violado en el caso porque la protección que el sistema francés proporcionaba a la demandante no satisfacía los requisitos procedimentales inherentes al art. $2 \mathrm{CEDH}$. 


\section{LA PROTECCIÓN ESTATAL ANTE CIERTOS TIPOS DE RIESGO PARA LA VIDA}

En este campo se está en presencia, como se ha indicado antes, de una línea jurisprudencial tan atractiva como peligrosa por lo que tiene de activista, pues, entre otras cosas, fiscaliza no sólo acciones - públicas e incluso privadas- sino también omisiones estatales. Los riesgos de muerte que deben ser protegidos por el Estado pueden provenir de (a) terceros, de (b) daños medioambientales graves o de (c) una insuficiente protección de las regulaciones jurídicas estatales en materias de proceso penal y organización penitenciaria.

\section{A) Riesgos provenientes de terceros}

La primera Sentencia y leading case en este apartado es el Caso Osman v. Reino Unido, de 28 de octubre de 1998. El asunto conmocionó a la opinión pública. Un profesor británico acosó, en el colegio, en la calle y en el domicilio familiar, a un discípulo y a su familia hasta que finalmente mató al padre con un arma de fuego e hirió gravemente al alumno. La demanda consideraba que el Estado había fallado en adoptar las medidas apropiadas para proteger la vida de los afectad os por los incidentes. El Tribunal argumentó que el art. 2 del Convenio implica en ciertas circunstancias una obligación positiva para las autoridades nacionales de adoptar medidas preventivas que protejan a un individuo cuya vida corra peligro por los posibles actos criminales de otro individuo. El Tribunal tiene en cuenta "las dificultades que entraña para la policía en las sociedades modernas la impredictible conducta humana y las elecciones tácticas que deben hacerse en términos de prioridades y recursos", de modo que una tal obligación "no debe interpretarse como una carga imposible o desproporcionada sobre las autoridades". Por ello, "no todo riesgo puede obligar a las autoridades a prevenir que se materialice". Otra relevante matización que efectúa el Tribunal es "la necesidad de asegurar que la policía ejercite sus poderes de controlar y prevenir el crimen de un modo que respete por completo el debido proceso y otras garantías que legítimamente restringen el ámbito de la acción de investigar el crimen y traer a sus autores a la justicia". A juicio del Tribunal, cuando se alegue que las autoridades han omitido su obligación positiva de proteger el derecho a la vida en el contexto de su deber de prevenir y evitar los delitos contra las personas, debe establecerse que "Ias autoridades conocían o deberían conocer la existencia de un riesgo real e inmediato sobre la vida" de un individuo o individuos concreto ante posibles actos criminales de un tercero y que han omitido las medidas que, en el ámbito de sus poderes, podrían juzgarse razonablemente que evitarían tal riesgo.

Este criterio, test o estándar sólo puede responderse a la luz de todas las circunstancias del caso particular. En el Caso Osman, por ejemplo, el Tribunal no estima violación 
del art. 2. ${ }^{47}$ Pero en el Caso A kkoc v. Turquía, de 10 de octubre de 2000, sí. ${ }^{48}$ En efecto, en este asunto el asesinado fue un maestro y activista kurdo amenazado. Aunque el Tribunal no pudo constatar que lo mataron las fuerzas de seguridad turcas, analiza, concluyendo afirmativamente, si el Estado turco había incumplido su obligación de proteger a ese señor de un riesgo conocido, real e inmediato, para su vida. Para alcanzar esa conclusión, el Tribunal constata "una carencia de responsabilidad de los miembros de las fuerzas de seguridad por sus acciones", incompatible con el rule of law en una sociedad democrática, derivada de tres graves defectos en la protección penal en esa región del sudeste turco durante el periodo relevante: (1으) Cuando los delitos eran cometidos por oficiales del Estado en ciertos casos la competencia para investigar pasaba del ministerio público a un consejo administrativo cuyo responsable era el Gobernador, director, a su vez, de las fuerzas de seguridad. (2ํ) El ministerio público habría mostrado escasa voluntad de perseguir los delitos cometidos por las fuerzas de seguridad en ese periodo y lugar. (3o) Los procedimientos judiciales contra el PKK eran sustanciados ante tribunales nacionales de seguridad que no cumplían los requerimientos de independencia impuestos por el art. 6 del Convenio debido a la presencia de un juez militar cuya participación permitía suponer el temor de una indebida influencia.

Otros casos interesantes en este punto son el ya citado Keenan, de 3 de abril de 2001, el de Kilavuz v. Turquía, de 21 de octubre de 2008, el de Paul y Audrey Edwards v. Reino Unido, de 14 de marzo de 2002, el de Yilmaz v. Turquía, de 17 de junio de 2008, o el de Branko Tomasic y otros v. Croacia, de 15 de enero de 2009. El primero se refiere a la demanda que presenta una madre contra las autoridades penitenciarias que no habían protegido a su hijo, enfermo mental, del suicidio. No prosperó porque, a juicio del Tribunal, las autoridades de la prisión habían adoptado las medidas necesarias (atención médica, etc.). En el segundo caso, muy parecido al primero, ya que también tenía que ver con el suicidio de un recluso con esquizofrenia, el Tribunal sí estimo, sin embargo, violación del art. 2 del Convenio. El caso Edwards se desarrolla en una cárcel inglesa, y se refiere al asesinato de un preso por su compañero de celda, un sujeto muy peligroso, desequilibrado psicológicamente y con bastantes episodios violentos en su currículo. Aquí sí aprecia el Tribunal violación del art. 2 porque no se informó de la peligrosidad del asesino, hubo una inadecuada entrada en prisión del asesinado, etc. En Yilmaz, el Tribunal estima incumplimiento estatal del deber de protección de la vida de una persona, también con problemas mentales, que se suicida; en este caso, la especificidad reside en que se trata de un militar. El caso Tomasic aborda un caso de violencia de género y por ello reviste un interés especial para nuestro ordenamiento. Un individuo asesina a su mujer e hija tras haberlas amenazado durante años e incluso después de haber cumplido una pena de prisión de cinco meses por ello. Al asesino se le había diagnosticado una enfermedad psiquiátrica, pero no se le ofreció tratamiento, por lo que el Tribunal consideró que el Estado no había cumplido su deber de protección de la vida de las dos víctimas, concluyendo,

\footnotetext{
47 Tampoco en Denizci y otros v. Chipre, de 23 de mayo de 2001, un caso en el que la demanda fue planteada por una turca ante el asesinato de su hijo en la parte griega de Chipre.

48 Y en otros como Kaya v. Turquía, de 28 de marzo de 2000 y en Kilic v. Turquía, de la misma fecha.
} 
por tanto, que habría habido lesión del art. 2 CR.

Otro asunto que podría tener interés como "doctrina inaugural" para otros casos es el resuelto en Pereira Henriques v. Luxemburgo, de 9 de mayo de 2006, referido a un accidente laboral. Un obrero resultó muerto accidentalmente en el curso de los trabajos de demolición de un inmueble. El Tribunal apreció en la legislación luxemburguesa algunos obstáculos en orden a que la familia del difunto obtuviera del empresario explicaciones sobre sus acciones y omisiones, de modo que consideró que se había violado el art. 2 del Convenio en su dimensión procedimental por carencia de una investigación efectiva de los hechos.

\section{B) Riesgos procedentes de daños medioambientales}

Se han dictado tres importantes Sentencias en este punto. La primera fue resolvió el Caso L.C.B. contra Reino Unido, de 9 de junio de 1998. La demandante es la hija de un militar británico que sirvió en el Pacífico durante las pruebas nucleares y estuvo, por consiguiente, expuesto a cierto nivel de radiación (en algunos casos, se pidió a la tropa que permaneciera en el exterior durante el bombardeo). Posteriormente, la demandante padeció leucemia infantil, que consideraba consecuencia directa de las radiaciones excesivas sufridas por su padre durante el servicio militar. El Tribunal examina si el Estado "hizo to do lo que se requería para prevenir que la vida de la demandante se expusiera a riesgo", atendidas las circunstancias del caso. El Tribunal sostiene, sin embargo, que no puede ser conocido con certidumbre si el padre fue sometido a niveles peligrosos de radiación (más bien, los informes manejados por él sugieren que la radiación no alcanzó niveles peligrosos en las áreas donde sirvió), y tampoco ha sido establecido ningún vínculo causal entre la exposición a radiación del padre y la leucemia de la hija concebida posteriormente. A demás, el Estado carecía de información suficiente en el tiempo relevante como para evaluar la posibilidad de tal relación (radiación/leucemia), por lo que no se le puede exigir que actuara de propia iniciativa en algún sentido. Por todo ello, no habría habido violación del art. 2.

La segunda Sentencia es la del Caso Guerra y otros v. Italia, de 19 de febrero de 1998. Los demandantes consideraban que la presencia a menos de un kilómetro de su población de una empresa química calificada de "alto riesgo" y con un historial de accidentes ponía de manifiesto que las autoridades no habían adoptado medidas apropiadas para reducir el riesgo de polución y evitar el riesgo de otros accidentes, con lo que se lesionaría su derecho a la vida. El Tribunal no estimó necesario examinar este problema desde el ángulo del art. 2 porque lo hizo desde la protección a la vida privada y familiar del art. 8 (como en el caso López Ostra). Pero el voto concurrente del juez Walsh apunta, según creo, en la buena dirección: habría habido también violación del art. 2 del Convenio. Más preciso es, en el mismo sentido, la opinión concurrente del juez Jambrek: "La protección de la salud y la integridad física están en estrecha relación tanto con el derecho a la vida como con el respeto a la vida privada y familiar. Podría ser tiempo para que la jurisprudencia del Tribunal sobre el derecho a la vida comience a 
considerar, desarrollando los respectivos derechos implícitos, las situaciones de riesgo serio y real para la vida o diferentes aspectos del derecho a la vida".

El Tribunal ha tenido ocasión de considerar directamente la protección contra riesgos derivados de graves daños medioambientales como exigencia del art. 2 en el Caso Oneryldiz v. Turquía, de 18 de junio de 2002. Nueve miembros de la familia del demandante murieron a consecuencia de un corrimiento de tierras de un vertedero. El Tribunal relaciona directamente protección de la vida y del medio ambiente: “El Tribunal debe primero apuntar que una violación del derecho a la vida puede relacionarse con cuestiones medioambientales capaces de plantear un serio riesgo para la vida". En esta conexión, "los recientes desarrollos de los estándares europeos a este respecto simplemente confirman una conciencia creciente de los deberes que incumben a las autoridades nacionales en el campo del medio ambiente, particularmente en relación con los vertederos y los riesgos inherentes". De aquí que el art. 2 sea aplicable en el caso. El Tribunal, para comprobar si el Estado cumplió su obligación, valora si estableció regulaciones preventivas (concluyendo negativamente) y si respetó el derecho del público a la información sobre los riesgos (tampoco). El Tribunal sostuvo que, en el presente caso, las autoridades conocían o deberían haber conocido que los habitantes de ciertas áreas de chabolas estaban expuestos a un riesgo serio y real de su integridad física y vidas debido a las deficiencias del vertedero municipal. En consecuencia, se produjo una violación del art. 2 . Pero el Tribunal va más allá y valora también si los procedimientos penales y administrativos de compensación han satisfecho los requerimientos del art. 2. Examina, por ejemplo, el proceso penal que se siguió considerando contrario a la Convención que el ministerio público calificara los delitos de un modo más benigno que otro, aunque dos responsables municipales fueron finalmente sancionados. Chequea también la compensación administrativa, concluyendo que se había pagado una indemnización escasa y, además, tarde. Habría habido violación del art. 2 también por "la ineficacia de la maquinaria judicial turca para remediar los daños en el presente caso". A mi juicio, el Tribunal no resistió la tentación a impartir justicia por sí mismo y me pregunto si lo hubiera hecho también si el Estado demandado no fuera Turquía sino otro de mayor pedigrí democrático. Desde el punto de vista técnico es difícil no compartir la opinión discrepante de los jueces Türmen y M aruste. El Tribunal no tuvo en cuenta que la casa se construyó de modo ilegal en terrenos prohibidos. Hubo una reparación penal y otra administrativa. “El tribunal nacional examinó los hechos y decidió aplicar el art. 230 del Código Penal turco y no el art. 455. Nada hay en el juicio que sugiera que el tribunal actuara arbitrariamente" La actuación del TEDH en este asunto es un claro ejemplo del Tribunal "actuando como una cuarta instancia".

C) Valoración por el Tribunal de sistemas penales y penitenciarios estatales a fin de examinar si protegen suficientemente la vida o reparan adecuadamente su pérdida

En Calvelli y Ciglio v. Italia, de 17 de enero de 2002, el Tribunal resuelve una demanda que alegaba que diversos retrasos procesales permitidos por el ordenamiento italiano habían impedido perseguir penalmente al doctor responsable por grave negligencia de la muerte de su hijo recién nacido. Aquí relaciona el Tribunal dere- 
cho a la protección de la vida y derecho a la protección de la salud: "Las obligaciones positivas mencionadas requieren a los Estados que establezcan regulaciones obligando a los hospitales, públicos y privados, a adoptar medidas apropiadas para la protección de las vidas de los pacientes. También requiere un efectivo sistema judicial que pueda establecer la causa de la muerte de los pacientes... y que los responsables respondan". Esta relación es atractiva desde el punto de vista conceptual, pero amenaza con abrir la puerta, vía art. 2, de Estrasburgo al derecho de daños por negligencias médicas con resultado de muerte, lo que no sería, lógicamente, de recibo. Pero volvamos a la argumentación de Calvelli, porque es interesante. Razona el Tribunal que incluso aunque la Convención no garantiza el derecho a ejercitar procesos penales contra terceros, él ha dicho en numerosas ocasiones que el efectivo sistema judicial requerido por el art. 2 podría, bajo ciertas condiciones, incluir el recurso al Derecho Penal. A hora bien, si la vulneración del derecho a la vida o a la integridad personal no es causada intencionadamente, la obligación positiva impuesta por el art. 2 para establecer un sistema judicial efectivo no requiere necesariamente la existencia de un remedio de Derecho Penal en todo caso. En la esfera específica de la negligencia médica, por ejemplo, la reparación podría ser satisfecha también ante los tribunales civiles. 0 mediante medidas disciplinarias. En el caso no habría habido violación del art. 2 porque aunque en el plano penal el delito prescribió, el demandante tenía abiertas las vías civil y disciplinaria. En Dodov v. Bulgaria, de 17 de enero de 2008, se planteaba otro asunto relativo al deber estatal de obligar a los establecimientos sanitarios, públicos y privados, a adoptar medidas apropiadas para la protección de la vida de sus pacientes, pero, a diferencia del caso anterior, no se trataba de un error médico, sino de una negligencia del equipo técnico de la institución, que había permitido a una enferma de Alzheimer, de 63 años, interna en la institución, abandonarla sin control para una consulta médica externa, con el resultado de que esa mujer desapareció. El Tribunal observó que el ordenamiento búlgaro contaba con tres vías para depurar en su caso responsabilidades (civil, penal y disciplinaria), pero en casos como ése no se aseguraba una posibilidad efectiva de reparación, por lo que consideró que se había producido una violación del art. 2 del Convenio. Una tercera Sentencia en esta línea de casos es Tarariyeva v. Rusia, de 14 de diciembre de 2006 . El Tribunal sostuvo que las autoridades rusas habrían violado el art. 2 del Convenio tanto en su dimensión sustantiva, por no haber prestado adecuado tratamiento médico a un recluso que lo precisaba, resultando su muerte a consecuencia de ello, cuanto en su dimensión procedimental al no haber existido una investigación oficial efectiva.

En el Caso Mastromatteo v. Italia, de 24 de octubre de 2002, el demandante acusaba a las autoridades nacionales de haber contribuido a crear las condiciones para el asesinato de su hijo porque éste lo había sido a manos de unos delincuentes que estaban disfrutando de régimen de prisión atenuada (permiso de salida y régimen semi-abierto). El Tribunal no considera, sin embargo, que el sistema de medidas alternativas a la prisión comprometa, en sí mismo, la responsabilidad del Estado bajo el art. 2 por la muerte de una persona causada por beneficiarios de tal sistema. El Tribunal reconoce el fin legítimo de una política de reintegración social progresiva de personas sentenciadas a prisión y examina a la luz del Convenio el sistema normativo italiano, 
concluyendo que está dotado de suficientes medidas de protección para la sociedad. Por tanto, "nada sugiere que las medidas de reintegración aplicables en Italia en ese tiempo deban cuestionarse bajo el art. 2".

\section{CONCLUSIONES FINALES}

El art. 2 del Convenio ha ido adquiriendo en la lectura que de él ha venido realizando el TEDH un significado en parte distinto al inicialmente previsto (que estaba ligado sobre todo a la pena capital) y, desde luego, mucho más amplio. Podría decirse que en el tiempo de aprobación del Convenio era firme la idea de la indisponibilidad privada de la vida (esto es, por parte de su titular), pero se permitía un cierto margen (sujeto en todo caso a límites, por supuesto) para la disponibilidad pública de la vida (es decir, por parte del Estado), mientras que, desde los años ochenta, se ha ido abriendo paso la tendencia general a considerar cada vez menos disponible la vida para los agentes públicos (abolición de la pena de muerte, entendimiento restrictivo de los límites del derecho a la vida, etc.), a la vez que se ha ido planteando con crudeza el debate sobre la disponibilidad "privada" de la propia vida. El Tribunal Europeo, en la Sentencia Pretty, no ha querido cerrar tal debate casi antes de haber empezado en los ordenamientos nacionales, con buen criterio, a mi juicio, pues asuntos tan complejos y socialmente divisivos como éste, en los que se entrecruzan intereses diversos, deben ser abordados en primer lugar en los Estados miembros como lugares idóneos de "experimentación", de "ensayo y error" y de maduración y contrastación de los argumentos en presencia.

La jurisprudencia del TEDH ha sido particularmente garantista respecto de la tutela jurídica de la vida, interpretando de modo astringente sus límites y avanzando al máximo los estándares de protección. Son destacables, en este sentido, aportaciones como la identificación de la dimensión procedimental del derecho, que ha permitido al Tribunal condenar a los Estados demandados por violación del derecho a la vida de personas (detenidas, encarceladas, desaparecidas, etc.) sobre las que no se ha tenido constancia, más allá de toda duda razonable, que hubieran sido asesinadas por las fuerzas de seguridad, pero sobre las que el Estado tenía un deber general de protección, de modo que éste tenía que haber realizado una "investigación oficial efectiva" pero no lo hizo. La precisa configuración de los contornos de tal investigación es otro hallazgo conceptual indudable del Tribunal. Es claro y constante el mensaje del TEDH de tolerancia-cero contra los excesos estatales de la lucha antiterrorista. Dentro de los nuevos significados del derecho consagrado en el art. 2 del Convenio, es interesante, sin duda, la ampliación de las obligaciones de protección del Estado que el Tribunal observa amparadas por él en relación con ciertos riesgos contra la vida de las personas, provenientes en algún caso incluso de otros particulares y no ya sólo de las fuerzas de seguridad estatales (recuérdese el caso $\mathbf{0}$ sman).

Pero la interpretación del Tribunal plantea también algunos problemas, aludidos en el texto. Fundamentalmente, tres:

(1ㅇ) Que el Tribunal se convierta en juez de los hechos, al modo de una tercera o cuarta instancia, suplantando con su decisión la adoptada antes por órganos judiciales 
mejor situados para apreciar y valorar las circunstancias del caso (recuérdese el significativo voto particular de nueve jueces a la Sentencia McCann).

(2ํ) Q ue, al conectar la protección de la vida, en el marco conceptual de la noción de "riesgo", con la tutela de otros bienes (salud, medio ambiente, seguridad), se abra todavía más las (ya de por sí amplias) posibilidades de enjuiciamiento del Tribunal (me remito a la valoración crítica de la Sentencia Oneryldiz) y la permanente tentación de hacer justicia en el caso concreto. Son de interés, en este sentido, las apreciaciones de ULRICH BECK ( La sociedad del riesgo, Paidós Básica, Barcelona 1998). Las sociedades industrializadas de la era tecnológica pueden escapar de la miseria pero ya no del riesgo y el miedo asociado; los peligros, que a menudo no son visibles, se han convertido en "polizones del consumo normal, viajan con el viento y el agua, están presentes en todo". Junto a la determinación científica del riesgo, emerge una percepción social del mismo, que también debe ser considerada. En este contexto, se producen muchos tipos de conflictos irreconciliables (porque a menudo no es posible una determinación científica exacta del problema) en los que se enfrentan expertos de toda clase. Estos conflictos desembocan a veces ante un juez. "La sistemática inseguridad de las ciencias, originada por la sobreproducción de resultados parciales, hipotéticos, inconexos y contradictorios interfiere en el sistema jurídico y abre espacios de decisión a jueces 'independientes'". Esto, concluye BECK, "representa la pluralización y politización de las deliberaciones jurídicas". Una de las consecuencias es que "legislador y administración acaben sentados, con mayor frecuencia, en el banquillo de los acusados". Las expectativas de procesos de revisión judicial en los casos de conflicto "crean una omnipotencia del papel de los jueces y reducen en espacio del juego del legislador y la administración". Esta posibilidad crítica, típica de la sociedad del riesgo, se agudiza en el caso del TEDH.

(3) Que, por el expediente de valorar si los ordenamientos estatales protegen de modo suficiente el derecho a la vida, el Tribunal se convierta en “juez de la convencionalidad" con capacidad para enjuiciar la compatibilidad con el Convenio de Roma, prácticamente en abstracto, además, y con una débil conexión al caso planteado, de ramas enteras del ordenamiento jurídico interno (derecho procesal penal, penitenciario, sanitario, riesgos laborales, etc.).

\section{ANEXO JURISPRUDENCIAL}

Doctrina general sobre el art. 2 del Convenio: McCann y otros v. Reino Unido, de 27 de septiembre de 1995.

Protección ante las muertes causadas por agentes del Estado:

- Fuerzas y operaciones especiales: McCann y otros v. Reino Unido, de 27 de septiembre de 1995;

- Requisitos de la investigación oficial efectiva: Jordan v. Reino Unido, de 4 de mayo de 2001;

- Inmovilizaciones policiales con resultado de muerte: Scavuzzo-Hager y otros v. Suiza, de 7 de febrero de 2006. 
- Desaparecidos: Çakici v. Turquía, de 8 de julio de 1999.

- Muertes en dependencias policiales: A ktas v. Turquía, de 24 de abril de 2003.

- Ataques racistas a la vida: Nachova y otros contra Bulgaria, de 6 de julio de 2005

Suicidio asistido: Pretty v. Reino Unido, de 29 de abril de 2002.

Estatuto jurídico del feto humano: Vo v. Francia, de 8 de julio de 2004.

Protección estatal ante riesgos para la vida provenientes de:

- Terceros: Osman v. Reino Unido, de 28 de octubre de 1998;

- Daños ambientales: Oneryldiz v. Turquía, de 18 de junio de 2002;

- Insuficientes regulaciones estatales procesales penales: Calvalli y Ciglio v. Italia, de 17 de noviembre de 2002, y penitenciarias: Mastromatteo v. Italia, de 24 de octubre de 2002. 